\title{
Interactions with Climate and Ecosystem of Saharan Dust Dynamics
}

\section{Sahra Tozu Dinamiklerinin İklim ve Ekosistem ile Etkileşimi}

\author{
Research Article
}

\section{A. Nihal Yücekutlu}

Hacettepe University, Faculty of Science, Department of Chemistry, Beytepe, Ankara, Turkey.

\section{ABSTRACT}

N orth African deserts are the world's largest sources of atmospheric mineral dust produced by aeolian. In this study the impact of various growth media on development of some bread wheat (Triticum aestivum L.) and durum wheat (Triticum durum L.) cultivars have been investigated. As a four different nutrient media, Hewitt nutrient solution [1], illuminated and non-illuminated Saharan desert soil solutions and distilled water have been utilized. Shoot length $\left(\mathrm{cm}\right.$. seedling $\left.{ }^{-1}\right)$, leaf area $\left(\mathrm{cm}^{2}\right.$ seedling $\left.{ }^{-1}\right)$ and photosynthetic pigments [chlorophyll a, chlorophyll b and carotenoids, $\mathrm{mg} \mathrm{ml}^{-1} \mathrm{~g}$ fresh weight $(\mathrm{g} \mathrm{fw})^{-1}$ ] have been determined. The results of this study indicate that, wheat varieties fed by irradiated Saharan soil solution gave comparable results to Hewitt nutrient solution.

\section{Key Words}

Saharan dust (mineral dust) event, climate change, ecosystems.

\section{ÖZET}

\begin{abstract}
U uzey Afrika çölleri atmosferik mineral tozun dünyada en büyük kaynağıdır. Bu çalışmada, farklı besin ortamlarının ekmeklik buğday (Triticum aestivum L.) ve makarnalık buğday (Triticum durum L.)'ın bazı çeşitlerinin fide gelişimi üzerine etkileri araştırılmıştır. Besin ortamı olarak; Hewitt besin çözeltisi [1], ışıklandırılmış ve karanlıkta bırakıımış Sahra çöl toprağı çözeltisi ve deiyonize su kullanılmıştır. Fide uzunluğu $\left(\mathrm{cm} . \mathrm{fide}^{-1}\right)$, yaprak alanı $\left(\mathrm{cm}^{2}\right.$.fide $\left.{ }^{-1}\right)$ ve fotosentetik pigmentler (klorofil a, klorofil b ve karotenoidler $(\mathrm{c}+\mathrm{x}$ ), $\mathrm{mg} . \mathrm{ml}^{-1} \mathrm{~g}$ taze ağırlık ${ }^{-1}$ ) belirlenmiştir. Bu çalışmanın sonuçları göstermektedir ki, aydınlatılmış Sahra toprak çözeltisi ile beslenen buğday çeşitleri Hewitt besin çözeltisi ile karşılaştırılabilir sonuçlar vermiştir.
\end{abstract}

\section{Anahtar Kelimeler}

Sahra tozu (mineral toz) olay, iklim değişikliği, ekosistemler.

Article History: Received: Oct 15, 2015; Revised: Nov 19, 2015; Accepted: Nov 20, 2015; Available Online: Dec 30, 2015.

DOI: $10.15671 /$ HJBC.20154315991

Correspondence to: A.N. Yücekutlu, Hacettepe University, Environmental Engineering Department, Beytepe, Ankara, Turkey. 


\section{INTRODUCTION}

aharan dust has important influences on $\checkmark$ nutrient dynamics and biogeochemical cycling in both oceanic and terrestrial ecosystems in North Africa and far beyond, due to frequent long-range transport across the Atlantic Ocean, the Mediterranean Sea and the Red Sea, to the Eastern American Coasts, Europe and the Middle East. The effect on the vegetative growth of plants of Saharan dust have been investigated and physical, chemical and mineralogical composition for its role in crop production have been analyzed [1-5]. In this review, Saharan dust inputs (mineralogical composition, microorganisms and enzymes, etc.) will investigate the role of natural fertilization effects on vegetation. Physical properties of the mineral dust as well as its chemical and mineralogical composition and state of mixing change its influence on climate and atmospheric chemistry [6].

Atmospheric aerosol (Figure 1) play important roles in numerous atmospheric processes such as cloud formation, modification of cloud properties, heterogeneous chemistry, and visibility degradation, all of which affect climate forcing [7]. In addition to the inputs of mineral and organic nutrients associated with dust events, viable bacteria are transported long distances with unknown implications for colonization of aquatic ecosystems and, consequently, for shaping biogeographical patterns of bacterial phyla [8].

Aerosols have major impacts on weather and climate regulations [9] and even on crop production [10]. The Mediterranean Sea atmosphere is subject to the continuous injection of Saharan and Middle East mineral dust particles [11]. The deposition of these mineral particles supply numerous macro and micro- nutrients to the ocean surface [12] and some authors consider it as the major source of "new" nutrients [13] for system production.

Aerosol particles containing atmospheric HUmic-Llke Substances (HULIS) can play an important role in continental environments [14]. In recent field studies organic materials, such as oxalic acid and humic-like substances (HULIS), have been shown to be present in mineral dust aerosoL. Mineral dust aerosol generated from windblown soil can contribute to climate forcing either directly through scattering or absorbing solar radiation or indirectly through acting as cloud condensation nuclei (CCN). The CCN activity of pure humic and fulvic acids has also been measured [15]. Within any ecosystem different variables can interact in complex synergistic or antagonistic ways [16].

Saharan soil may have bio-available iron and also some essential macro and micro nutrient elements suitable for use as fertilizer for growing wheat. Possible impacts of elemental composition of Saharan dust on the growth parameters of some selected wheat varieties were investigated [2]. It has been shown that Saharan soil may have the potential of producing bioavailable iron when illuminated with visible light and also it has some essential macro and micro nutrient elements [3]. These are the key elements of a research proposal.

\section{MATERIAL AND METHODS}

\section{Saharan Desert Soil and Saharan Desert Soil Solution Analysis}

In this research, Saharan desert raw soil samples taken from southern Tunisia, near Tozeur has been used. In laboratory the raw soil samples dried, sieved (30 mesh) and homogenized. Some physical and chemical analyzes of a homogeneous soil of the Saharan desert, Laboratory of Soil (Soil and Water Resources, Central Research Institute, Ankara, Turkey) were conducted. Saharan desert soil samples were analyzed by X-Ray diffraction (Philips W1140 model) using CuKa radiation and a gonimeter speed of $2 \mathrm{deg} / \mathrm{min}$ at Hacettepe University department of Geological Engineering.

Atomic Absorption Spectrophotometer (Perkin Elmer 2280 model) and ion chromatography (Dionex 600 model) analyses of the liquid were taken immediately. These analyses were conducted in Hacettepe University, International Research and Application Center for Karst Water Resources [3].

\section{Experimental Design}

Laboratory experiments were performed in controlled climate chamber and in randomized design. In this application has been simulated the nature. 


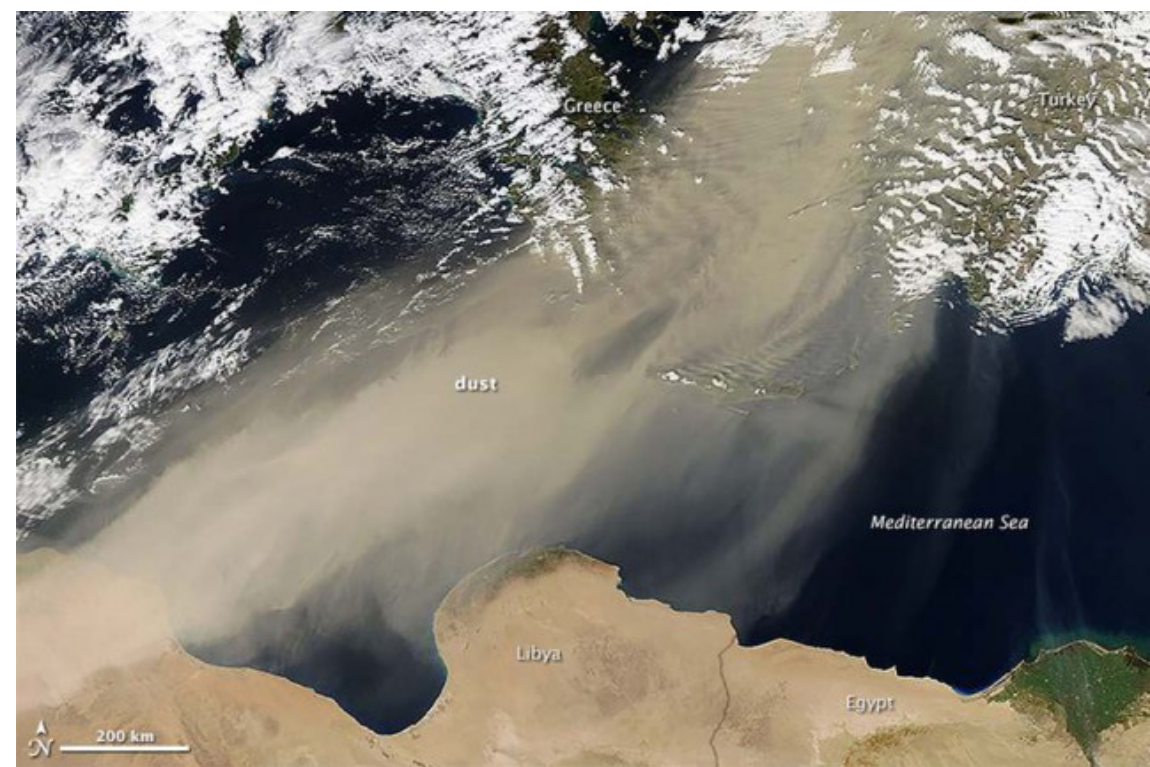

Figure 1. Saharan Dust over the Mediterranean Sea.

In early February 2015, Greece and Turkey was pummeled by strong southwesterly winds. http://wordlesstech.com/2015/02/05/saharan-dust-plumed-the-mediterranean-sea/

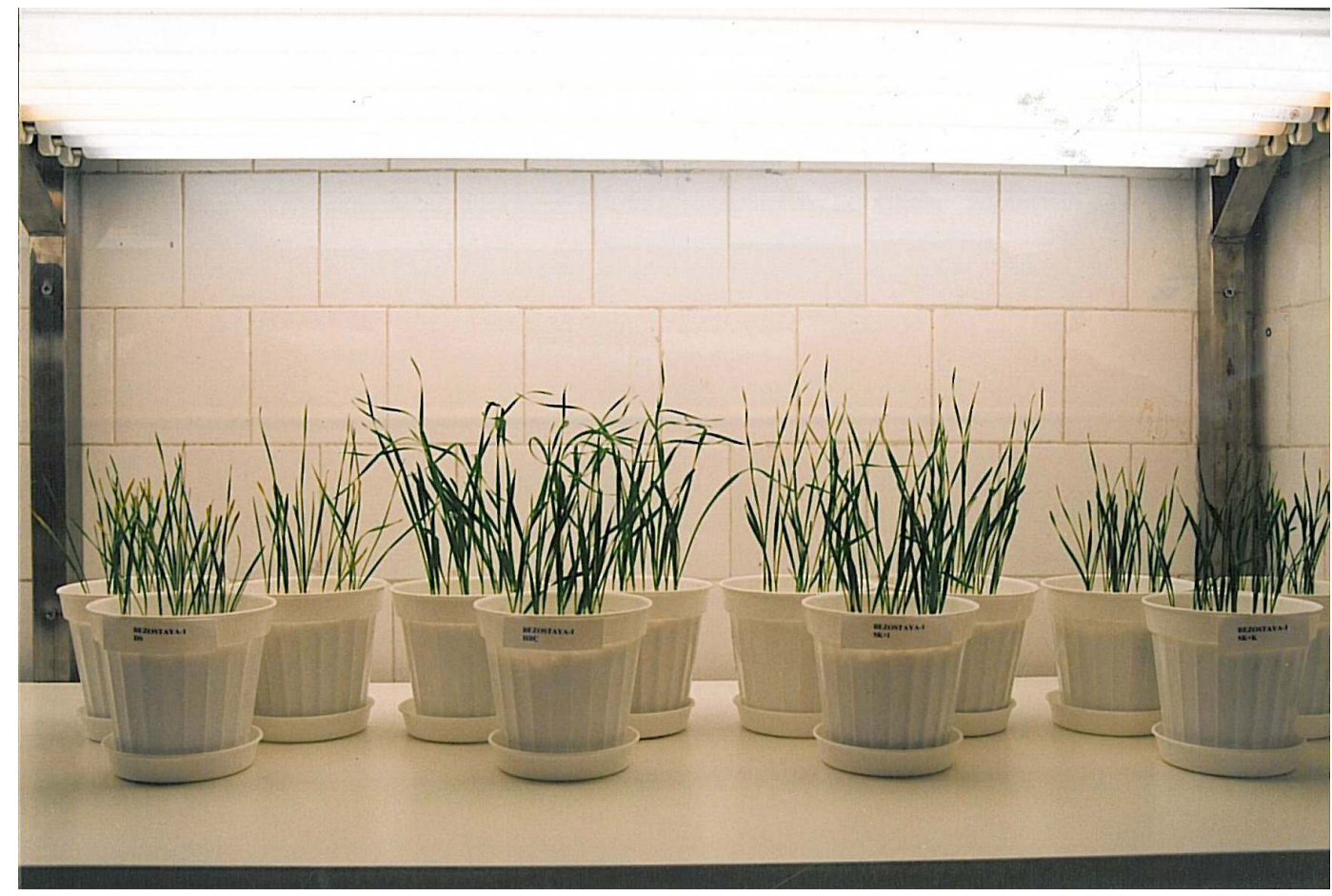

Figure 2A. $10 \times 16 \mathrm{~cm}$ perlit containing pots, the experiments were performed in randomized desing.

4 application $\times 3$ replicates $\times 5$ cultivars, Yücekutlu (2004) M.Sc. (The growth media were; D.W., H.N.S., SDSS+I and

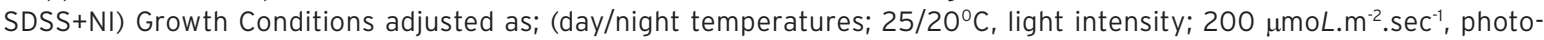
periods, light/dark; 16/8 h/day, humidity; 45\%), (40 days experimental period). 


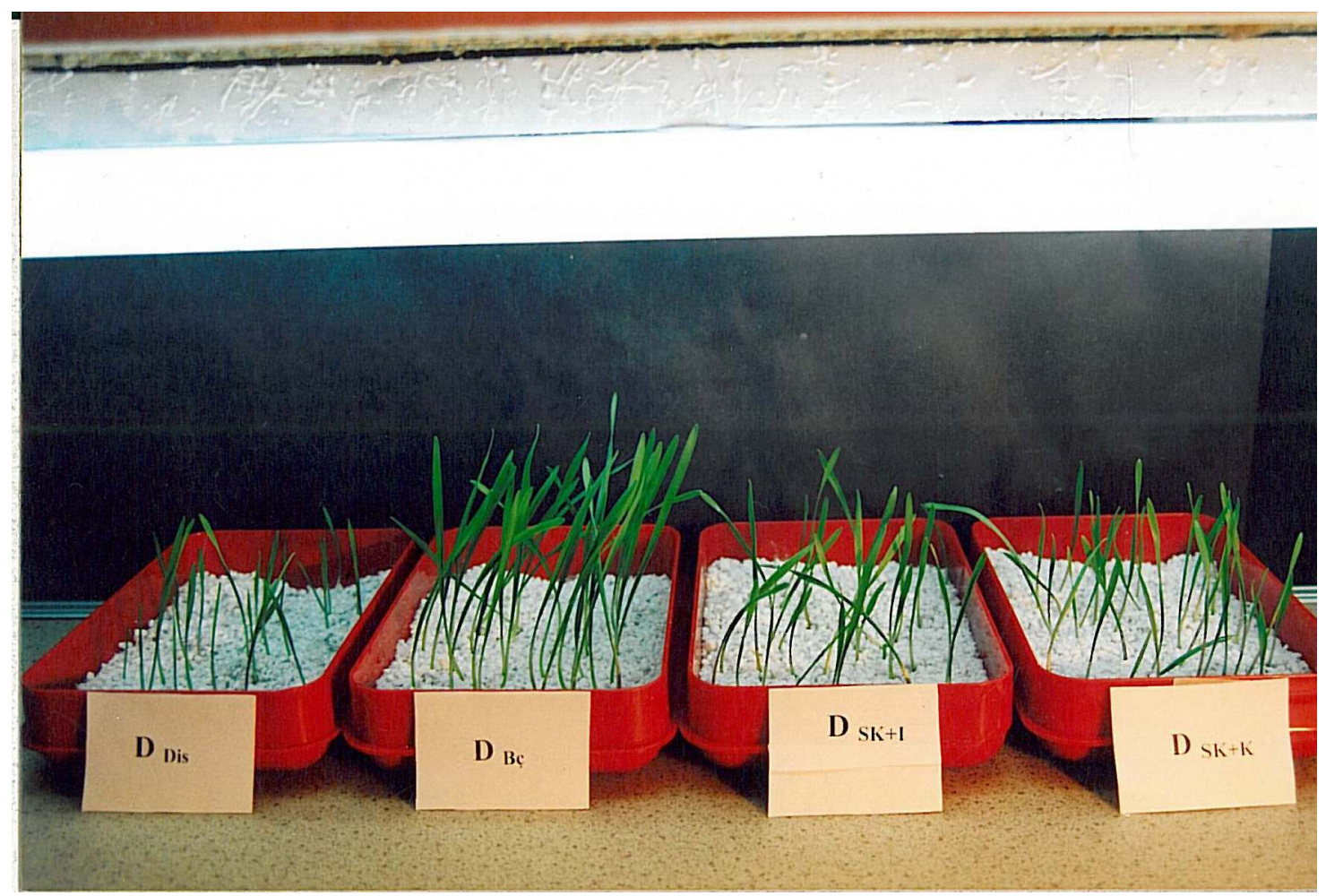

Figure 2B. Seedling development in germination containers (10 days experimental period), (Yücekutlu, 2004) M.Sc

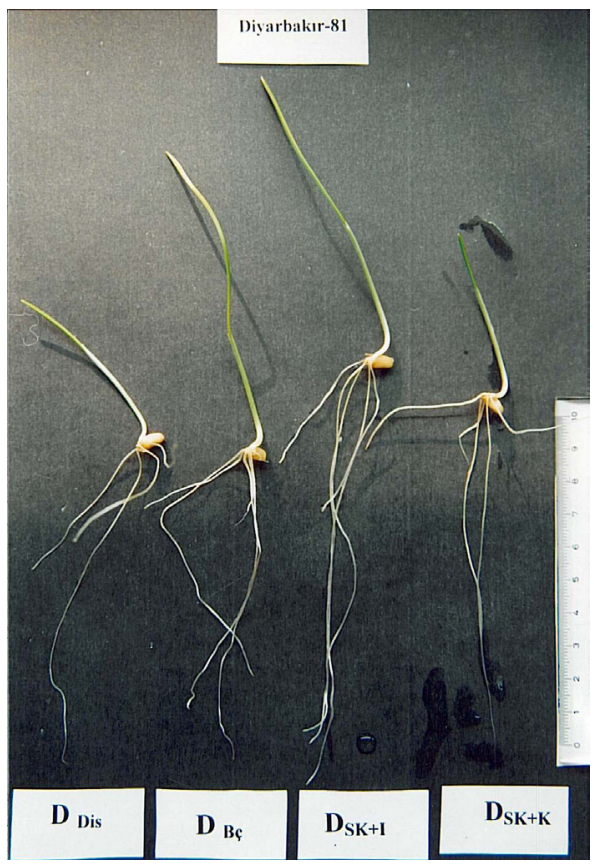

Figure 2C. Diyarbakır-81 durum wheats spring types cultivar (length of seedling, fringe number and length of root) (10 days experimental period), (Yücekutlu, 2004) M.Sc 
Table 1. The most responded were given above by comparison of the seedling length at different growth media and Hewitt Nutrient Solution. First and second cultivars among the others (The determined growth parameters at Hewitt Nutrient Solution are accepted as 100).

\begin{tabular}{ccc}
\hline Growth Parameters & \multicolumn{2}{c}{ Culvitars } \\
\hline & 1 & 2 \\
\hline Morphologic parameters & & \\
\hline Seedling length & Diyarbakır-81 (\%81) & Harran-95 (\%75) \\
\hline Leaf area & Harran-95 (\%84) & \\
\hline Photosynthetic parameters & & Kın-91 (\%83) \\
\hline Chl a & Diyarbakı1 (\%97) \\
\hline Chl b & Diyarbakır-81 (\%99) & Bezostaya-1 (\%96) \\
\hline Carotenoids $(\mathbf{x}+\mathbf{c})$ & Diyarbakır-81 (\%99) & Çukurova-86(\%96)
\end{tabular}

Elite seeds of the cultivars were obtained from Central, South and South-East Agricultural Research Institute in Turkey.

\section{Test Material}

-Bread wheat's (Triticum aestivum L.);

- Winter type ; Bezostaya-1

- Spring type ; Çukurova-86

- Durum wheat's (Triticum durum L.);

- Winter type; KızIItan-91,

- Spring types; Harran-95, Diyarbakır-81 cultivars were used.

\section{Four different growth media}

- Hewitt Nutrient Solution, (H.N.S.) [1]

- Illuminated Saharan Desert Soil Solutions, (SDSS+I)

- Non- illuminated Saharan Desert Soil Solutions, (SDSS+NI)

- Deionize Water (D.W.)

\section{Growth Condition}

Controlled growth chamber;

- day/night temperatures; $25 / 20$ OC

- light intensity; $200 \mu \mathrm{moL} \cdot \mathrm{m}^{-2} . \mathrm{sec}^{-1}$

- photoperiods, light/dark;16/8 h/day

\section{RESULTS}

The climate chamber with plant specimens grown of image Figure 2A, 2B and 2C. As shown in Table 1, D-81 was the most responded cultivar within the others for the determined parameters. Consequently, future research may be focused probably on D-81.

\section{Analyses of the Saharan Soil}

Physical, chemical properties and mineralogical composition of Saharan desert soil were analyzed. Mineral analyses of the used Saharan desert soil sample are composed of quartz, calcite, gypsum and feldspar [3].

\section{DISCUSSION}

The significance of seedling length, leaf area and photosynthetic pigments content on vegetative growth productivity in the controlled climate chamber has been studied.

Despite some significant deficiencies and excesses of some nutritional elements it has been shown that comparable growth parameters achieved by using Saharan desert soil samples and no toxic effects have been observed.

\section{CONCLUSION}

The biogeochemical implications of Saharan soil dissolved mineral on vegetation growth have been investigated [3]. Agricultural activities over the experiments signified itself with a fertilizer factor. The climatic role of desert dusts is an important question in the critical discussion on global change. 
Atmospheric dusts are an important part of the global climate system, and play an important role in the marine and terrestrial biogeochemical cycles of major and trace nutrient elements.

The natural variations in atmospheric dust deposition are crucial for understanding the response of dust on ecosystems.

Our measurement strategy is aimed at obtaining a significant amount of information on the nature of the Saharan dust aerosols during extreme events in which the dust is transported and deposited in the plot region of LIDAR (LIght Detection And Ranging) data [17]. Results of these research efforts will potentially lead to new instruments that can be used to provide better observations for weather and climate change research.

\section{References}

1. E.J. Hewitt, Sand and water culture methods used in the study of plant nutrition, Tech. Com. No. 22 (Revised 2nd edition) comm. (1966) Bur. Hort. and Plantation Crops.

2. A.N. Yücekutlu, The investigation of possible impact of elemental composition of Saharan dust on the growth parameters of some selected wheat varieties, Master of Science Thesis, Hacettepe University, Department of Environmental Engineering, (2004).

3. A.N. Yücekutlu, S. Terzioğlu, C. Saydam, and I. Bildacı, Organic Farming By Using Saharan Soil: Could It Be An Alternative To Fertilizers? Hacettepe J. BioL. and Chem., 39 (2011) 29-37.

4. A.N. Yücekutlu (2012), 8th International Soil Science Congress on "Land Degradation and Challenges in Sustainable Soil Management, Volume 5, Investigation of the impact on vegetative growth of Saharan desert dust, (2012) 487-497.

5. A.N. Yücekutlu, ATMOS'2013, 6th Atmospheric Science Symposium, Istanbul Technical University (ITU), Investigation of the dynamic transport of Saharan Desert Dust-II, (2013) April 24-26.

6. J. Helmert, B. Heinold, I. Tegen, O. Hellmuth, and M. Wendisch, On the direct and semidirect effects of Saharan dust over Europe: a modeling study. J. Geophys. Res. 112 (2007) D13208.
7. I. Koren, Y.J. Kaufman, D. Rosenfeld, L.A. Remer, and Y. Rudich, (2005). Aerosol invigoration and restructuring of Atlantic convective clouds, Geophys. Res. Lett., 32 (2005) L14828.

8. C.A. Kellogg, DW. Griffin, Aerobiology and the global transport of desert dust. Trends EcoL. EvoL. 21 (2006) 638-644..

9. B.B.B. Booth, N.J Dunstone, PR. Halloran, T. Andrews, N. Bellouin, Aerosols implicated as a prime driver of twentieth-century North Atlantic climate variability. Nature 484 (2012) 228-232.

10. X. Liu, Y. Zhang, Han W, A. Tang, J. Shen, et aL.. Enhanced nitrogen deposition over China. Nature, 494 (2013) 459-462. .

11. J. Pey, X. Querol, A. Alastuey, F. Forastiere, M. Stafoggia, African dust outbreaks over the Mediterranean Basin during 2001-2011:PM10 concentrations, phenomenology and trends, and its relation with synoptic and mesoscale meteorology. Atmospheric Chemistry and Physics, 13 (2013) 1395-1410. .

12. S. Bonnet, C. Guieu, J. Chiaverini, J. Ras, A. Stock, Effect of atmospheric nutrients on the autotrophic communities in a low nutrient, low chlorophyll system. Limnology and Oceanography, 50 (2013) 1810-1819. .

13. E. Ternon, C. Guieu, C. Ridame, S. L'Helguen, P. Catala, Longitudinal variability of the biogeochemical role of Mediterranean aerosols in the Mediterranean Sea. Biogeosciences, 8 (2011) 1067-1080. .

14. S. Fuzzi, M.O. Andreae, B.J. Huebert, M. Kulmala, T.C. Bond, M. Boy, S.J. Doherty, A. Guenther, M. Kanakidou, K. Kawamura, V. Kerminen, M., Lohmann, U., Russell, U. Pöschl, Critical assessment of the current state of scientific knowledge terminology, and research needs concerning the role of organic aerosols in the atmosphere, climate, and global change, Atmos. Chem. Phys., 6 (2006) 2017-2038.

15. K.M. Gierlus, Laboratory Studies of The Physicochemical Properties Of Mixed Organic/Mineral Dust Atmospheric Aerosols: Hygroscopicity And Cloud Condensation Nuclei Activity. Theses and Dissertations. This dissertation is available at lowa Research Online: http://ir.uiowa.edu/etd/2704, (2011).

16. C.L. Folt, C.Y. Chen, M.V. Moore, and J.L. Burnaford: Synergism and antagonism among multiple stressors, LimnoL. Oceanogr., 44 (1999) 864-877.

17. N. Yücekutlu, and Y. Yücekutlu, 17th International Conference on Advanced Laser Technologies (ALT'09), Impacts of the Transport of Aerosols from Saharan Dust and Lidar Techniques, Book of Abstracts pp. 30-31, 26 Sept.-1 Oct.2009, Turkey. 